OnLine Journal of Earth Sciences 4 (1): 6-12, 2010

ISSN: 1991-7708

(C) Medwell Journals, 2010

\title{
Ultrabasic Massif of Goleshi (Kosova): Microstructural and Kinematic Analysis
}

\author{
${ }^{1}$ Islam Fejza, ${ }^{1}$ Sabri Avdullahi, ${ }^{2}$ Avni Meshi, ${ }^{1}$ Murat Meha and ${ }^{1}$ Ahmet Tmava \\ ${ }^{1}$ Faculty of Mining and Metallurgy, University of Prishtina, Kosovo, \\ 40000 Parku Industrial, Mitorovic \\ ${ }^{2}$ Faculty of Geology and Mining, Polytechnic University of Tirana, Albania
}

\begin{abstract}
The Goleshi Peridotite massif is representative of the dippest mantle section of the Vardar oceanic lithosphere: these deep mantle peridotite are characterized by the lack of pyroxenite dykes, gabbroic dykes, chromite ore bodies and the presence of rare and small dunite lenses. The ophiolitic peridotite of the Goleshi massif is thrust above metamorphic Palaeozoic-Triassic series and is overlain by transgressive Pliocene formations. The foliation strikes north-eastward and dips $40^{\circ}$ northwestwards. A northwards plunging lineation is measured in the foliation plane all over the massif. Microstructure analysis's of harzburgites have revealed the presence of low temperature $\left(800-1000^{\circ} \mathrm{C}\right)$ porphyroclastic and mylonitic texture of implying a deviatory stress between 580 and 1100 bar. These microstructural features relate to the deformations of oceanic lithosphere, during upper Jurassic convergence, when an intraoceanic thrust break up formed at or close to the mid-oceanic ridge. Kinematic analysis reveals that the hangingwall of this thrust was transported from West to East.
\end{abstract}

Key words: Oceanic lithosphere, mantle, harzburgite, porphyroclastic texture, mylonitic texture

\section{INTRODUCTION}

The study of ophiolites is an important contribution as regarding the origin, the generation of the old oceanic lithosphere and obduction of their fragments on continental edges. The ophiolites of Balkan are among the best representatives of the old Neotethys lithosphere of Triassic-Jurassic age and for this reason, they were always the objects of numerous studies.

A recent debate about the origin of this ophiolite consists in an alternative: does this ophiolite belong to an oceanic lithosphere generated within a single ocean or have different oceanic lithospheres been generated between several micro-continents detached from Gondwana.

Pamiæ et al. (2002) suggest that remnants of a Triassic oceanic lithosphere of the Neotethys (Maliata-Maliac) are part of an ophiolitic mélange structurally overlain by the Dinaride-Albanide Hellenide ophiolite; the latter being slices of oceanic lithosphere of Vardar Neotethys branch generated between the Adria microplate and the European plate. In this context, the eastward plunging subduction of Jurassic-Cretaceous time has enabled the obduction of Vardar oceanic lithosphere fragments over Adria micro-plate (Bortolotti et al., 2005; Bortolotti and Principi, 2005; Tremblay et al., 2008). In contrast, the majority of geologists who have worked in the Balkan area consider the Dinaride-Albanide-Helenide ophiolite as remnants of the Neotethys oceanic lithosphere generated from two or more oceanic marginal basins (Channell and Kozur, 1997; Robertson, 2002; Robertson and Shallo, 2000; Karamata, 2006; Dilek et al., 2008).

The oceanic break up and its accompanying lithospheric deformation is already evidenced in the basal mylonitic peridotites of several ophiolite massifs of the Balkan area (Boudier et al., 1982, 1988; Ceuleneer et al., 1996).

The Goleshi massif represents one of these massifs in which the basal mylonite peridotite have registered the Vardar inter-oceanic break up event. The all geological cartographic presentations in Kosovo are in a new coordinate system Kosovaref.

This geodetic datum was defined with the establishment of the 1st order reference network KOSOVAREF01 as Gauss Krüger projection on the European Terrestrial Reference System, ETRS89 (GRS80 ellipsoid) as standard for a new surveying systems in Europe (Meha, 2005). The excellent outcropping conditions of the fresh harzburgite facies of Golesh massif (Kosovo) is very suitable for kinematical and structural studies of a fossil oceanic lithosphere.

Corresponding Author: Sabri Avdullahi, Faculty of Mining and Metallurgy, University of Prishtina, Kosovo, 40000 Parku Industrial, Mitorovic 


\section{MATERIALS AND METHODS}

Geological context of peridotic massif of Golesh: The Goleshi peridotite massif is a part of the Vardar ophiolites in the central part of Kosova (Fig. 1). The strike of the

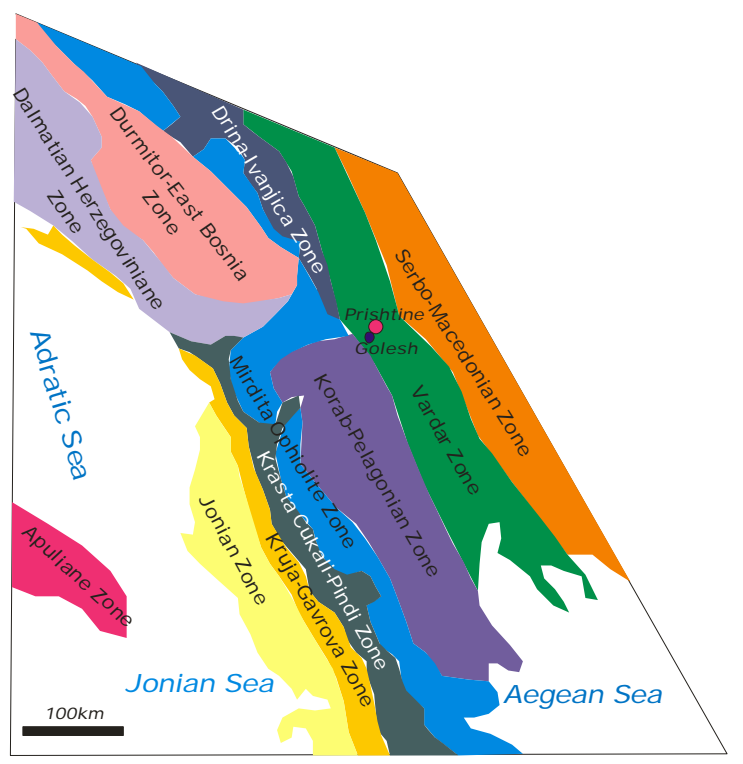

Fig. 1: Simplified geological map of the west-central Balkan Peninsula

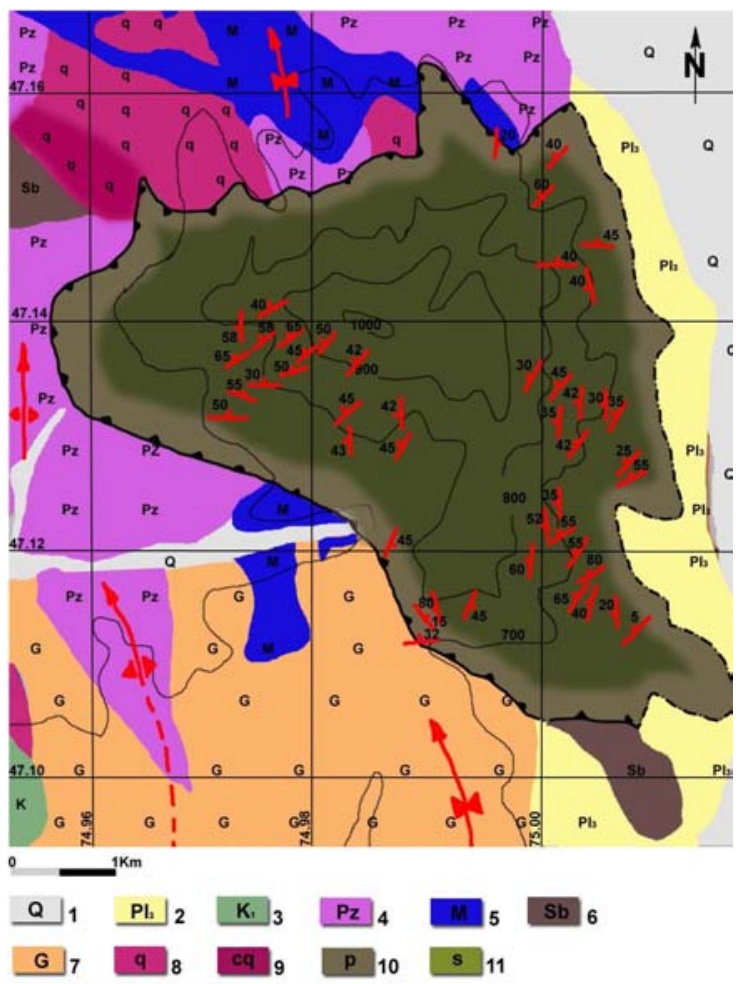

Fig. 2: Map of foliation in the mantle section of the Goleshi massif showing major tectonic zones massif is NW-SE and its dimensions are $7 \times 4.5 \mathrm{~km}$. The ultramafic massif of Golesh is composed solely of harzburgite with thin and rare lenses of dunite, transposed during asthenospheric and lithospheric deformation. The nearly total lack of pyroxene dykes and chromite ore bodies is a characteristic feature of this massif. The basement of the massif is constituted by a slice of serpentinite schists varying in thickness from $4-10 \mathrm{~m}$. The serpentinite slice is $>100 \mathrm{~m}$ thick and it gradually passes upwards to the fresh hartzburgite facies (Fig. 2). Magnesite concentrations which vary largely in size are hosted by serpentinised harzburgite and serpentinite and they become industrial concentrations in the southern and southeastern parts of the massif. In the eastern part of the massif, a weathering crust is widely developed, represented by laterite with high grade of nickel silicate ore and covered by Pliocene formations. The laterization of the peridotite in the continental conditions occurred within a short period of time, a few thousands years only (Marc-Antoine Audet, personal communication) which means that the time of laterite formation is Pliocene. The metamorphic basement of Golesh ophiolite actually is not in a normal position due to tectonic reasons. A small lense-like metamorphic sole, only several metres square is tectonically exposed under the serpentinite in the south-western part of the massif. It is composed of wrinkled schists with centimetric quartz lenses which represent the remnants of fold axes in the shape of knife case. The dip direction of the micaschist schistosity is $80^{\circ}$ NW $32^{\circ}$ whereas lineation is $55^{\circ} \mathrm{NE} 5^{\circ}$. Fold axes are parallel to the lineation in micaschists. Huge serpentinite schists are developed over the micaschist lense and chrysotile-content increases according to the direction $330^{\circ}$ which plunges at $20^{\circ}$. Kinematic markers over the serpentinite schists (in the peridotite ) show a motion sense of the massif towards SSE. In Arilaq village, in the northern part of the massif, the fault contact between peridotite and Palaeozoic metamorphic rocks, is a fault plane oriented $345^{\circ} \mathrm{E} 20^{\circ}$ with a striation with plunging direction $30^{\circ}$ and plunging angle $8^{\circ}$. Kinematic indicators testify for the tectonic emplacement of the Goleshi massif over Palaeozoic and Triassic formations. This motion is probably related to the latest alpine tectonic events. The most widespread Palaeozoic rocks are: gneiss, quartzite, metamorphosed conglomerate of quartzite facies, micaschist, marbles and calcschist and also metamorphic sandstone-biotitic schist and quartzite. Both in handspecimen and under the microscope right lateral ductilebrittle shears in biotitemicaschists. This structure is further complicated by micro- up to regional trend folds with NNW trending axes with a plunge toward the NNW (Fig. 2). 

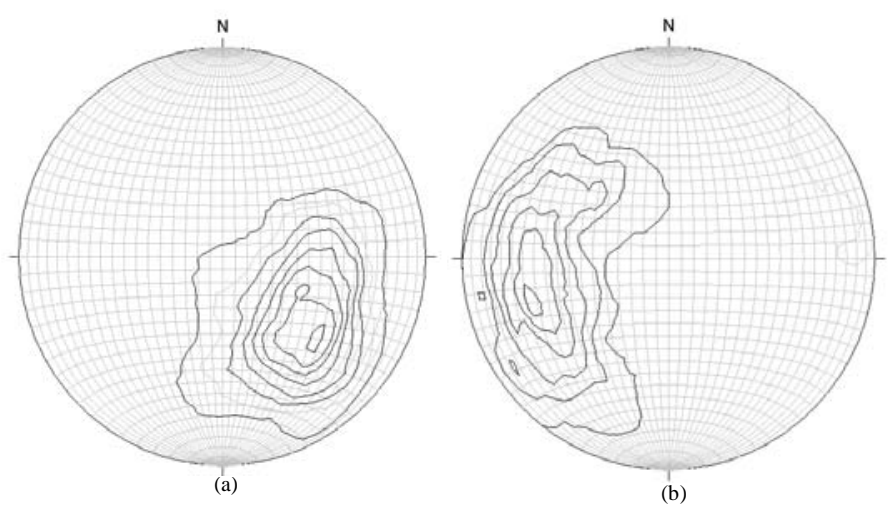

Fig. 3: Stereographic projections (lower hemisphere) of structural elements of the Goleshi massif: a) Poles to low-T foliations (92 measurements); contours $2,4,6,8,10,12,14,16 \%$, ( b) Low-T lineations (54 measurements); contours $2,4,6,8,10,12,14 \%$

Internal structures of mantle peridotites: The internal structures of mantle peridotites (Fig. 2 and 3 ) are analysed in details. The banding in peridotite of the massif is very well expressed and is represented mainly by pyroxene/harzburgite and less by pyroxene/dunite. This banding is always parallel to the foliation and for this reason their structural behaviour is similar. A foliation (Fig. 2) is observed in the basal peridotites which have registered lithospheric deformations. The pressure plans of the pyroxene and spinel can easily be observed in the field. Generally, when these two foliations are observed at the same station, they are parallel. Based on the statistical processing of 84 measurements (Fig. 3). The average direction of foliation is $38^{\circ} \mathrm{W} 39^{\circ}$. Of these $79 \%$ have an average direction $37^{\circ} \mathrm{W} 39^{\circ}, 13 \%$ have average direction $320^{\circ} \mathrm{SW} 78^{\circ}$ and $8 \%$ have average direction $241^{\circ} \mathrm{S} 54^{\circ}$. The plastic deformation in lithospheric conditions (Fig. 4) is studied by measuring the mineral stretching direction in the foliation plane. The direction of stretching of the spinel is measured in most cases and more rarely the stretching direction of pyroxene. Based on the statistical processing of 62 measurements (Fig. 3) that the average dip direction of lineation is $258^{\circ}$ and dipping angle $35^{\circ}$. Of these, $68 \%$ have a average dip direction $259^{\circ}$ and dipping angle $35^{\circ} ; 21 \%$ have an average dip direction $5^{\circ}$ and dipping angle $20^{\circ}$, whereas $11 \%$ have average dip direction $120^{\circ}$ and dipping angle $48^{\circ}$.

Textural and kinematic analysis: The textural classification of mantle peridotites of the Golesh massif is based on the model proposed by Harte (1977) and Mercier and Nicolas (1975) which is further applied by Boudier et al. (1988). The peridotites were derived from a very superficial level of oceanic mantle you say at the beginning that it is a deep part of the ophiolitic mantle where temperature changes very fast as function of

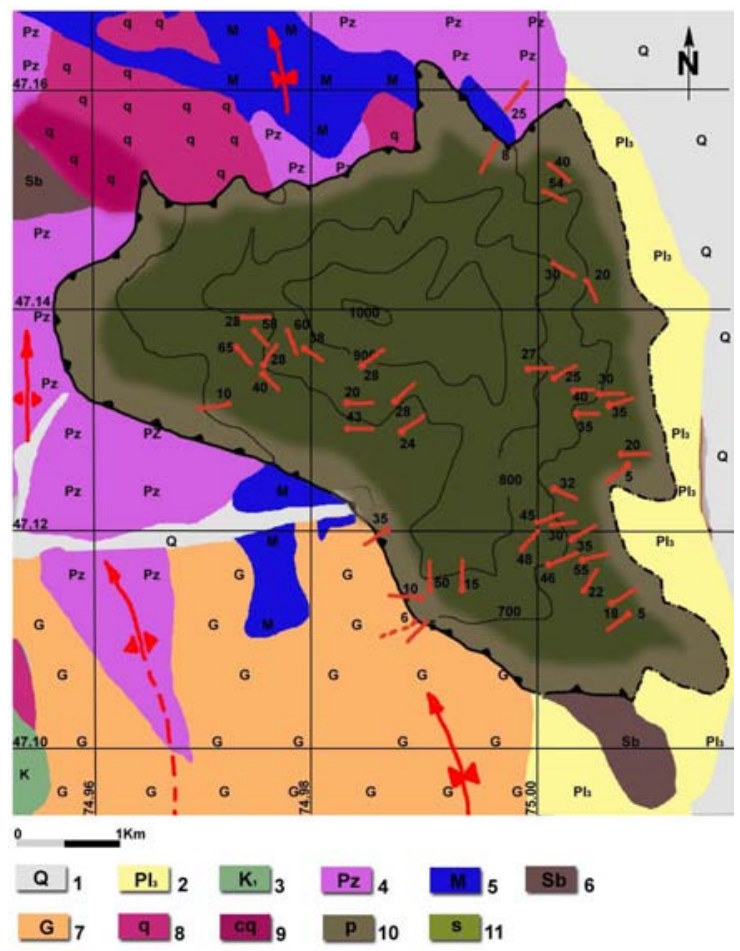

Fig. 4: Map of lineation in the mantle section of the Goleshi massif

distance and depth. So, the history of deformation of ophiolitic peridotites is controlled by their thermal evolution. The temperature during plastic deformation of ophiolitic peridotites is controlled by their thermal evolution. The temperature during plastic deformation of peridotites can be indirectly evaluated through microstructural criteria (Nicolas, 1978). This makes possible to distinguish structures formed during oceanic accretion (defor-mation at High Temperatures around $1200^{\circ} \mathrm{C}$ ) from those, which were formed in lithospheric 


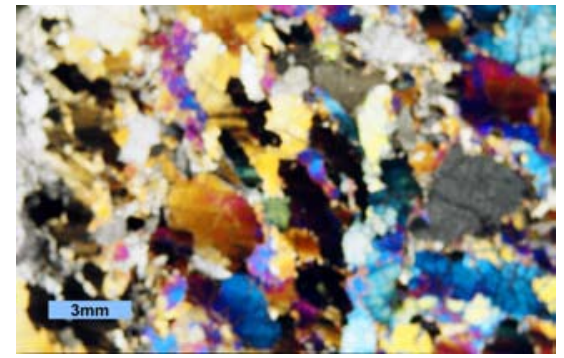

(a)

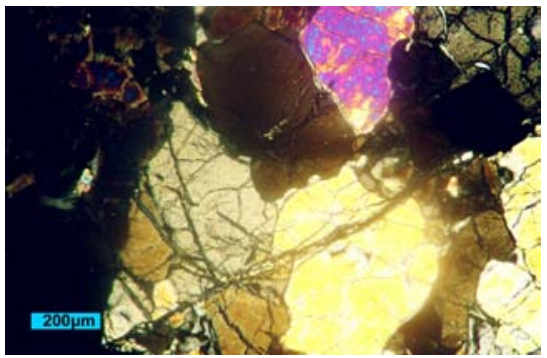

(c)

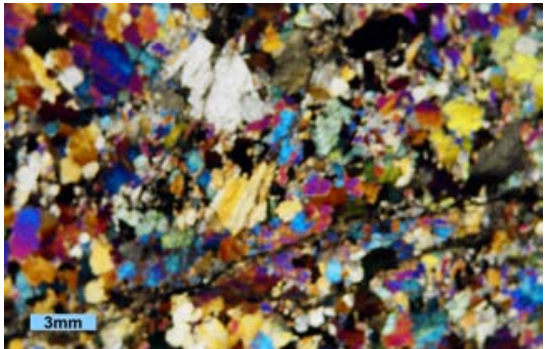

(b)

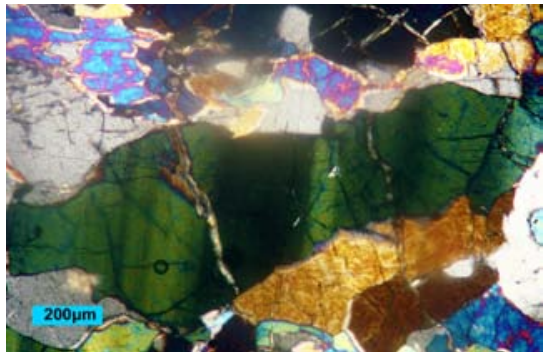

(d)

Fig. 5: (a) Low-T porphyroclastic texture in harzburgite from Goleshi massif, (b) Mylonitic texture in harzburgite from Goleshi massif, (c) Triple points of olivine's neoblasts, (d) Tight substructures in porphyroclasts of olivines

conditions (deformation at Low Temperatures around $800-1000^{\circ} \mathrm{C}$ ). In Goleshi massif, only the deformations of low temperature are recorded (lithospheric deformation). Both microstructural studies and kinematic analysis of mantle flow have been performed in thin sections. The oriented samples from which thin sections were prepared are regularly spaced in the field. The oriented samples have been treated with diluted chlorhydric acid to determine foliation and lineation in laboratory conditions. The shear direction has been determined from the difference between the fabric of the shape and fabric of the net, using especially narrow sub-structures in olivine porphyroclasts, which are deformed in low temperatures (lithospheric deformations). High-temperature microstructures are only locally encountered in the upper part of mantle section. They are represented by coarse grained granoblastic textures (several $\mathrm{mm}$ ), both as equant and tabular ones. The presence of bended linear contours, which form triple points at $120^{\circ}$ is also observed. Wide sub-structures related to an important restoration during joints migration are another characteristic feature. Because of the restoration during asthenospheric deformation at high temperature, wavy extinction is almost absent. Macroscopic expressions of plastic deformation structures (foliation and lineation) are moderated to the light ones. Their preferred orientation is very strong, showing a small difference between the plastic flow directions and the foliation trace. Low-temperature microstructures of are present almost in the whole massif. They are characterised by a grain size reduction, related to the dynamic recrystallisation (fine-grained porphyroclastic microstructures, Fig. 5a), inducing the formation of neoblasts and dislocation walls. The last one is expressed with the development of narrow dislocation substructures in olivine (Fig. 5d) accompanied with intense wavy extinction. This evolution leads to submylonitic microstructures and further to mylonitic ones (Fig. 5b). Kink-bands observed in orthopyroxenes is a characteristic feature of mantle peridotite deformation in lithospheric conditions. Macroscopic deformation features, foliation and lineation) are very strong and they increase together with the reduction of grainsize. Porphyroclastic textures predominate in massif (Fig. 5a), where about $50 \%$ of olivine is re crystallised around olivine porphyroblasts, which are further exchanged. In a matrix of olivine neoblasts that create triple points (Fig. 5c). Mylonitic textures are only locally observed (Fig. 5b) where around $90 \%$ of them belong to the olivine neoblasts. They are located at the eastern part of massif, which constitutes the lower part of the fresh harzburgites, close to the serpentinite at the base of massif. Locally and in the upper part of mantle peridotites coarse-grained granoblastic textures are evidenced. The textural and microstructural analysis of samples taken in the Goleshi massif made possible to distinguish the field of lithospheric plastic deformations which are considered to be related to the intraoceanic, which has followed the accretion of asthenospheric mantle in lithosphere (second deformation lithospheric). The sense of motion along a shear zone can be recognized as the 


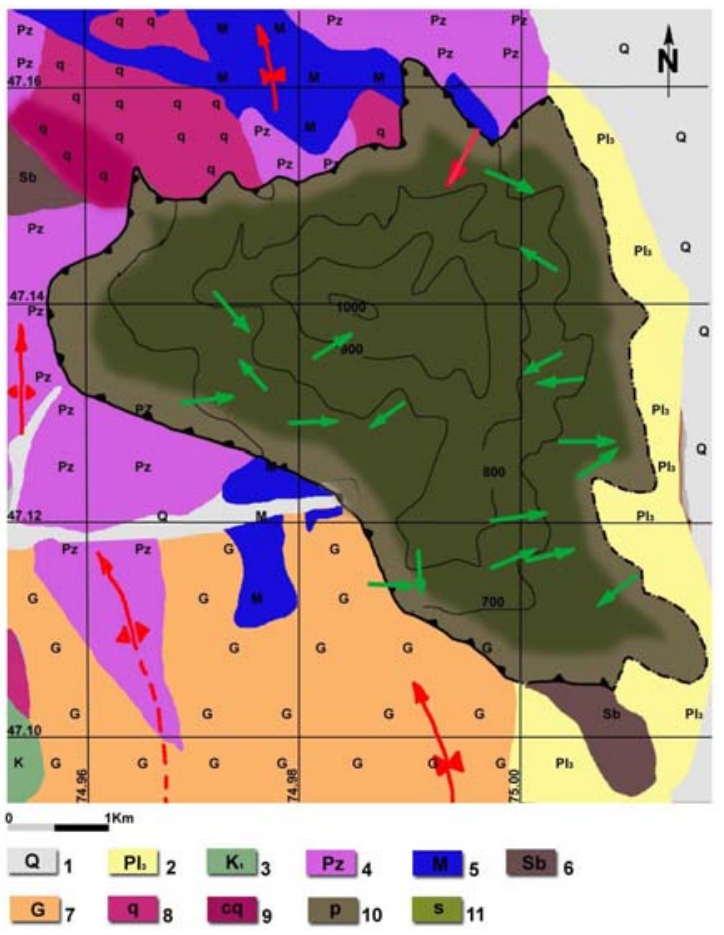

Fig. 6: Map of kinematics indicators in the mantle peridotites. Single arrow indicating the movement of the upper part with respect to the lower one

sense of rotation indicators in the $\mathrm{XZ}$ plane of finite strain. From 18 determinations showing the sense of mantle flow of the upper part in relation to the lower part during lithospheric deformation (Fig. 6), 10 determinations show a shear sense toward the East, 6 determinations show a shear sense toward the West and 1 determination shows a shear sense toward the South. Deformation intensity $\mathrm{Y}$ is calculated with formula $\mathrm{Y}=2 \operatorname{cotg} 2 \theta$ where, $\theta$ is the angle between the liding plan (C) and foliation (S). Y values vary from 1.68-11.34. In the lower part of massif and while approaching the basal serpentinites an increase of $\mathrm{Y}$ values is observed. Estimation of paleostrains is based on theoretical consideration (density of dislocations, size of subgrains) and on experimental calibration (Goetze, 1975). Particularly, the olivines of ophiolitic peridotites have been studied in detail by many researchers (Mercier and Nicolas, 1975; Gueguen, 1977). An estimation of paleostrains during asthenospheric deformations, based on the olivine size was used for the peridotite of Bulqiza massif (Mirdita ophiolite, Albania). For the calculation of deviatory strains recorded in mantle peridotites of Goleshi massif, we have used experimental calibration of Karamata (2006). This calibration refers to the dimensions of olivine neoblasts measured in basal peridotites of low temperatures with porphyroclastic, submylonitic and mylonitic texture. The dimensions of these neoblasts vary between 0.24 and $0.05 \mathrm{~mm}$ that coincide with values of deviatory strains between 580 and 1100 bar. These values are typical of the old stage of intraoceanic charriage.

\section{RESULTS AND DISCUSSION}

Discussion and interpretation of mantle flow structure in asthenospheric or lithospheric conditions, for structure of veins in mantle sequence, structure of the sheeted dikes complex etc., is done after the rotation of paleo Mohos back to horizontal.

Unfortunately in the Goleshi massif, the paleo-Moho is not present, therefore it makes difficult the discussion and structural and geodynamic interpretation of generation and closure of an oceanic basin. To overcome this problem, we have assumed that the mantle flow was originally horizontal. The lithospheric foliation in the basal peridotite of Goleshi massif has NE average direction and dip direction towards $\mathrm{NW}$ at $40^{\circ}$. The plunging direction is towards $\mathrm{W}$ at $35^{\circ}$. Structures almost subparallel with structures of the peridotite are also present in the metamorphic basement. A slight folding has locally deformed them (Fig. 3). Structural analysis reveals that the deformation relates to the complex kinematics of the convergent stage in this part of Neotethyan ocean of Vardar.

Thus, the plastic deformation in lithospheric conditions is due to interoceanic thrusting in thin sheets at the mid-ocean ridge which preceded the obduction, has createded these structures. The micaschists of the metamorphic sole, which are tectonically exposed under the basal peridotite are considered to be caused by oceanic crust metamorphism. So, we will discuss here only the lithospheric flow model which has registered the event of interoceanic thrusting. Microstructural analysis show a low temperature $\left(900-1000^{\circ}\right)$ deformation of and deviatory strain about 580-100 bar which fits very well conditions of beginning of intraoceanic, in or close to a ridge (Boudier et al., 1988). This is one of the criteria, which support our hypothesis.

A fossilized asthenospheric diapir in the moment of beginning of convergent stage; a metamorphic facies of high temperature (amphibolite with garnet) of metamorphic basement the sub-mantle shear zones in the peridotite which are deformed in asthenospheric conditions (Boudier et al., 1988) etc., are some of the features which are missing in the Goleshi ophiolite. A slice of basal peridotite approximately $500-800 \mathrm{~m}$ thick is exposed in this massif. As compared to ophiolites of 
Oman and Mirdita, this makes up almost the half of the thickness of basal the peridotites exposed in those massifs (Boudier and Nicolas, 1995). It is probable that the slice of basal peridotites belongs to the upper part of the massif.

The presence of relics of high temperature textures within the low temperature porphyroclastic textures which is seen mainly in the upper part of mantle harzburgites, do support the above-mentioned hypothesis.

Rare presence of mylonitic textures which are encountered only in the lower part of fresh harzburgites is a strong argument to support the lack of less than half of lower part of basal peridotites of Goleshi ophiolite. It is known that in the other massifs the thickness of the basal peridotite reaches up to $1.5-2 \mathrm{~km}$. It is confirmed that in the Mirdita ophiolite the structures of lithospheric deformation, which are registered during intraoceanic charriage are sub parallel to the Moho (Nicolas et al., 1999).

Kinematic analysis suggests a transport toward the East but this contrasts with most geodynamic schemes regarding the Vardar ophiolite belt.

There are two possible explanations: the massif has been horizontally rotated at $180^{\circ}$ and in such a case the eastern part of the massif is thrusted over the western part which fits well with all schemes proposed up to now or in the initial stage of convergence involved a west-dipping thrust which fits well with our kinematic data.

An initial transport parallel to the ridge during the initial stage of convergence, which is evidenced in many ophiolites, would imply the clock-wise rotation at $70^{\circ}$ of Golesh massif by tectonic events after the initial stage of convergence.

\section{CONCLUSION}

This is in contrast with all the previous geodynamic schemes dealing with the convergence and closure of Vardar Ocean. This could be explained by a multiple fragmentation of Vardar oceanic lithosphere. Today, most geologists support the opinion that the Vardar ophiolite represents a mélange in addition the size of Goleshi massif is small, so it would be difficult to find arguments to support the opinion for a west-dipping subduction.

The research shows that this massif is not a mélange. Later Alpine thrusts, which have transported this $m$ assif from north to south, might have strongly modified the initial position of basal peridotites, which have registered here the intraoceanic charriage stage.

\section{REFERENCES}

Bortolotti, V. and G. Principi, 2005. Tethyan ophiolites and Pangea break-up. Island Arc, 14: 442-470.

Bortolotti, V., M. Marroni, L. Pandolfi and G. Principi, 2005. Mesozoic to Tertiary tectonic history of the Mirdita ophiolites, Northern Albania. Island Arc, 14: 471-493.

Boudier, F. and A. Nicolas, 1995. Nature of moho transition zone in the Oman ophiolite. J. Petrol., 36: 777-796.

Boudier, F., A. Nicolas and J.L. Bouchez, 1982. Kinematics of oceanic thrusting and subduction from basal sections of ophiolites. Nature, 296: 825-828.

Boudier, F., G. Ceuleneer and A. Nicolas, 1988. Shear zones, thrusts and related magmatism in the Oman ophiolite: Initiation of thrusting on an oceanic ridge. Tectonophysics, 151: 275-296.

Ceuleneer, G., M. Monnereua and I. Amri, 1996. Thermal structure of a fossil mantle diapir inferred from the distribution of mafic cumulates. Nature, 379: 149-153.

Channell, J.E.T. and H.W. Kozur, 1997. How many oceans? Meliata, Vardar and Pindos oceans in Mesozoic Alpine paleogeograpgy. Geology, 25: 183-186.

Dilek, Y., H. Furnes and M. Shallo, 2008. Geochemistry of the Jurassic Mirdita Ophiolite (Albania) and the MORB to SSZ evolution of a marginal basin oceanic crust. Lithos, 100: 174-209.

Goetze, C., 1975. Sheared lherzolites: From the point of view of rock mechanics. Geology, 3: 172-173.

Gueguen, Y., 1977. Dislocation in mantle peridotite nodules. Tectoniphysics, 39: 231-254.

Harte, B., 1977. Rock nomenclature with particular relation to deformation and recrystatilization textures in olivine bearing xenoliths. J. Geol., 85: 279-288.

Karamata, S., 2006. The geological development of the Balkan Peninsula related to the approach, collision and compression of Gondwanan and Eurasian units. Geol. Soc. Lond. Spec. Publ., 260: 155-178.

Meha, M., 2005. Annual report. EUREF Symposium Held at Vienna, Austria 1-4 June 2005. http://www. eurefiag.net/symposia/2005Vienna/6-14.pdf.

Mercier, J. and A. Nicolas, 1975. Textures and fabrics of upper mantle peridotites as illustrated by xenoliths from basalts. J. Petrol., 16: 454-487.

Nicolas, A., 1978. Stress estimates from structural studies in some mantle peridotites. Philos. Trans. R. Soc. Lond. Ser., 288: 49-57.

Nicolas, A., F. Boudier and A. Meshi, 1999. Slow spreading accretion and mantle denudation in the Mirdita ophiolite (Albania). J. Geophys. Res., 104: $15155-15167$. 
Pamiæ, J., B. Tomljenoviæ and D. Balen, 2002. Geodynamic and petrogenetic evolution of Alpine ophiolites from the central and NW dinarides: An overview. Lithos, 65: 113-142.

Robertson, A.H.F. and M. Shallo, 2000. Mesozoic-Tertiary evolution of Albania in its regional Eastern Mediterranean context. Tectonophysics, 316: 197-254.
Robertson, A.H.F., 2002. Overview of the genesis and emplacement of Mesozoic ophiolites in the Eastern Mediterranean Tethyan region. Lithos, 65: 1-67.

Tremblay, A., A. Meshi and H.J. Édard, 2008. Oceanic core complexes and ancient oceanic lithosphere: Insights from Albanian and southern Quebec ophiolites. Tectonophysics, 473: 36-52. 